Portland State University

PDXScholar

\title{
A study of families with stress related to the care of children with myelomeningocele
}

Janet L. Ferguson

Portland State University

Russel Tweed

Portland State University

Follow this and additional works at: https://pdxscholar.library.pdx.edu/open_access_etds

Part of the Clinical and Medical Social Work Commons, Congenital, Hereditary, and Neonatal Diseases and Abnormalities Commons, and the Nervous System Diseases Commons Let us know how access to this document benefits you.

\section{Recommended Citation}

Ferguson, Janet L. and Tweed, Russel, "A study of families with stress related to the care of children with myelomeningocele" (1971). Dissertations and Theses. Paper 1414.

https://doi.org/10.15760/etd.1405

This Thesis is brought to you for free and open access. It has been accepted for inclusion in Dissertations and Theses by an authorized administrator of PDXScholar. Please contact us if we can make this document more accessible: pdxscholar@pdx.edu. 
AN ABSTRACT OF THE THESIS OF Janet L. Ferguson and Russel Tweed for the Master of Social Work presented May 21, 1971.

Title: A Study of Families With Stress Related To The Care Of Children With Myelomeningocele

APPROVED BY MEMBERS OF THE THESIS COMMITTEE:
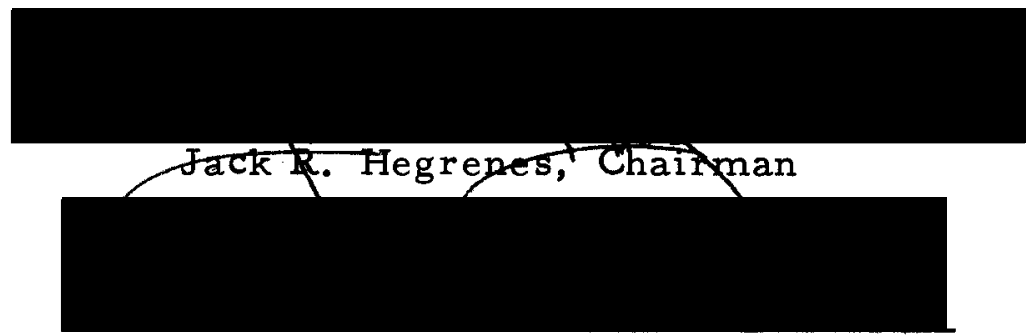

Thelma Danilson

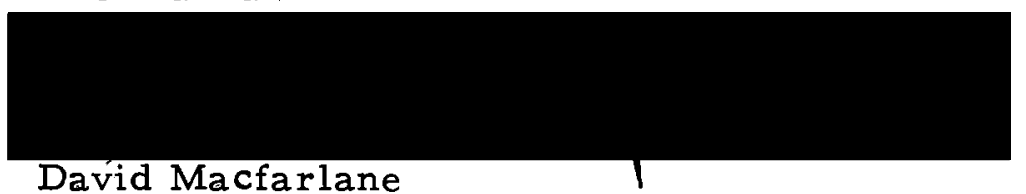

This was an exploratory-descriptive study of fifty children afflicted with myelomeningocele, ages one through six, who were known to the Myelomeningocele Clinic of the Crippled Children's Division. The study identified the degree of multiple physical, emotional, and environmental stress factors that families must be prepared to cope with.

The study identified eleven factors felt to play an important role in family dynamics and how they related to the families response to their child with myelomeningocele. The factors were tested and found to be valid by the use of a pre-test on ten case records. 
Medical records were then obtained from the Crippled Children's Division for chart review purposes and the appropriate material was recorded. Scores we re developed that indicated the degree of stress ranging from minimal involvement to maximum involvement.

The study found that a majority of the families in the sample live within commuting distance to needed medical services, have transportation available to them and generally utilize the necessary medical care appropriately. The remainder of the study showed, however, that families could be expected to face a variety of other problems that could only serve to increase family stress. Most of the families had limited financial resources. Over one-half of the families needed special education for their children. A majority of families had no medical insurance. Fifty-eight percent of the families were found to have additional stressful problems to cope with e.g., marital stress, sibling rivalry, additional ill members, etc. Added to this was the information that the child with myelomeningocele was found to be greatly involved in a multiplicity of medical problems at many different levels of functioning, e.g., orthopedic, bowel, neurosurgical, etc., that would be expected to add to the already stressful family dynamics.

Among the recommendations developed was a plea for the expansion of the satellite clinic concept, development of parent groups on a geographical basis, development of educational programs for 
educators and community service personnel, brief orientation programs for parents with the goal of helping them understand and integrate the health care system that they find themselves in. 
A STUDY OF FAMILIES WITH STRESS RELATED TO

THE CARE OF CHILDREN WITH MYELOMENINGOCELE

by

JANET L. FERGUSON

and

RUSSEL TWEED

A thesis submitted in partial fulfillment of the requirements for the degree of

MASTER OF SOCIAL WORK

Portland State University

1971 
TO THE OFFICE OF GRADUATE STUDIES:

The members of the Committee approve the thesis of Janet L. Fergusion and Russel Tweed presented May 21, 1971.

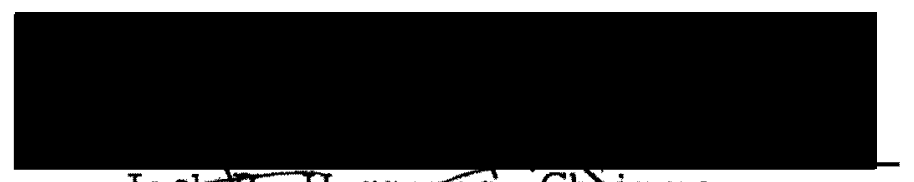

Jaek Hegrenes, Chajman

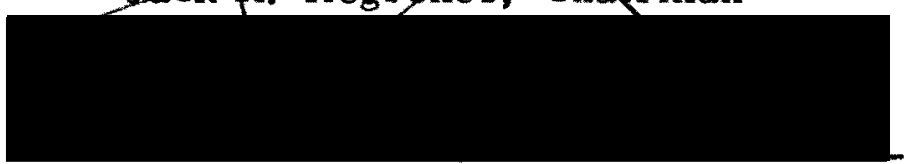

Thelma Danilson

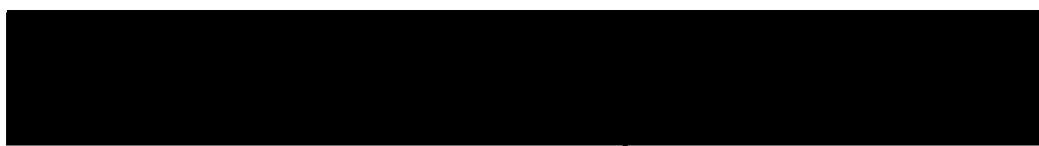

David Mcfarlane, M. D. I

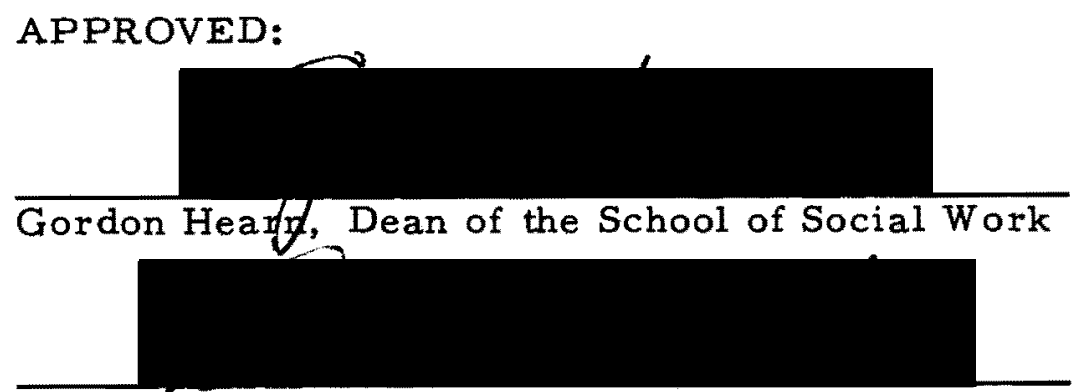

David T. Clark, Dean of Graduate Studies 


\section{ACKNOWLEDGEMENTS}

We reserve this page to express our appreciation to the members of the Crippled Children's Division Staff who gave of their time and counsel to assist in bringing this study to fruition. We are especially indebted to Dr. Richard Sleeter, Director of Crippled Children's Division for his permission to use institutional records.

Most deserving of praise is Thelma Danilson, ACSW, Social Worker for the Myelomeningocele Clinic for her inspiration of the study and her ever enthusiastic counsel throughout the project.

Special thanks must go to Jack R. Hegrenes, Ph. D, Assistant Professor of Social Work, who gave not only of his time and personal resources, but also constant support, encouragement, and guidance.

For specialized help, we wish to recognize the valuable assistance of Dr. David Macfarlane, Associate Professor of Pediatrics, for his constructive and illuminating suggestions,

Finally, we wish to express our sincere gratitude to our spouses, Karen Tweed and Clyde Ferguson, for their patience with our involvement on this thesis, often to the point of personal sacrifice. 
TABLE OF CONTENTS

PAGE

LIST OF TABLES

v

LIST OF FIGURES vi

CHAPTER

I INTRODUCTION 1

Background of Study . 1

Description of the Agency 5

Description of Myelomeningocele 8

II REVIEW OF LITERATURE 10

III METHODOLOGY 19

$\begin{array}{ll}\text { Description of Sample } & 19\end{array}$

Description of Weighting Procedures 19

Description of Instrument Design 20

Statistical Method Used 29

$\begin{array}{lll}\text { IV FINDINGS } & 30\end{array}$

Accessibility of Services Category 32

Financial Category 33

Insurance Category $\quad 35$

Family Environmental Stress Category 36

$\begin{array}{ll}\text { Educational Status } & 38\end{array}$

Intellectual Level Category $\quad 39$ 
Use of Medical Resources

Orthopedic Involvement 41

Kidney Bladder Involvement $\quad 42$

Bowel Involvement $\quad 44$

Neurosurgical Involvement $\quad 45$

Additional Handicap Involvement 46

$\begin{array}{ll}\text { Problem Multiplicity Category } & 47\end{array}$

V COMMENTS AND CONCLUSIONS 49

Suggestions for Change $\quad 53$

Implications for Further Research 56

$\begin{array}{ll}\text { BIBLIOGRAPHY } & 57\end{array}$

$\begin{array}{ll}\text { APPENDIX A } & 62\end{array}$

$\begin{array}{ll}\text { APPENDIX B } & 65\end{array}$

$\begin{array}{ll}\text { APPENDIX C } & 67\end{array}$

$\begin{array}{ll}\text { APPENDIX D } & 69\end{array}$ 


\section{LIST OF TABLES}

TAB LE

PAGE

I Ratings of Outcome

II Age and Sex Distribution 30

III Distribution by Race 31

IV Living Situation 31

V Method of Transportation $\quad 32$

VI Accessibility of Services 34

VII Financial Distribution $\quad 35$

VIII Insurance Distribution 36

IX Family Environment Stress $\quad 37$

$\begin{array}{lll}X & \text { Incidence of Stress Factors } & 37\end{array}$

$\begin{array}{lll}\text { XI Educational Status } & 39\end{array}$

$\begin{array}{ll}\text { XII Intellectual Level } & \mathbf{4 0}\end{array}$

XIII Incidence of Orthopedic Involvement 42

XIV Incidence of Kidney-Bladder Involvement 43

XV Incidence of Bowel Involvement 44

XVI Incidence of Neurosurgical Intervention . 45

XVII Incidence of Additional Handicaps 46 
CHAPTER I

\section{INTRODUCTION}

\section{BACKGROUND OF STUDY}

This thesis project was developed out of a field placement experience over a nine month period for student social workers at the Crippled Children's Division, University of Oregon Medical School. The students had been assigned to the Myelomeningocele Clinic (one of several different multiple discipline clinics within the Division) for the purpose of developing and improving social work skills. The children in this group are "at risk" many times in early life and have multiple, rather than single handicapping conditions. Personnel in helping professions, e.g. social workers, need to experience what it means to integrate multiple, fragmented services before they can teach parents how to do so effectively. The parents in this group were found to need constant consultation, advocacy, and intervention by social workers on their behalf if they were to be effective in the maintenance of a well planned, sustained, life-span care program. Doctors and others in helping professions need to understand family situations and stress related to the care of the child with myelomeningocele. 
It was through this experience that interest was manifested in the problems of family stress and health care management as it related to the myelomeningocele population at the Crippled Children's Division.

One variable that influenced the decision to use the younger age group was the relatively recent organizational composition of the Multiple-Discipline approach practiced by the Crippled Children's Division staff. This approach grew out of the realization that this group of children, requiring constant medical supervision by a number of specialists needed to be seen as whole beings rather than as a series of problems unrelated to each other. In times past, the child was seen by the neurosurgeon following his hospital discharge if the possibility of developing hydrocephalus existed. He was referred to an orthopedist when necessary, but not routinely seen for urological studies. Some families thought that seeing specialists eliminated the need for a pediatrician or a general practitioner. No one integrated the services for the family or helped them maintain preventive treatment. Because of this, some parents were not aware of fecal or urinary incontinence until after the stage of normal toilet training was outgrown and they were dismayed to find that their child was excluded from most child care and public schools. In the Myelomeningocele Clinic, goals for these children are reviewed at appropriate intervals for more positive planning. These group conferences are followed by 
conferences with the parents. The role of the social worker is one of implementation of treatment recommendations, being a liaison with the community and educational services and of providing continuous consultation to families between clinic appointments.

It was surprising and somewhat disappointing to realize that there was little recorded information about family emotional reaction when confronted with caring for a child with myelomeningocele. It was apparent, however, that there were many concomitant physical factors, such as kidney failure, hydrocephalus, etc., that affect the child with myelomeningocele and that identifying the stress factors affecting families with these children might be worthwhile. In the absence of subjective data related to this decision, it was decided to select or isolate factors which the students and the clinic personnel considered potentially stressful. It was known from experience that the stress for this group of families was great because of the multiplicity of handicapping conditions; because of medical complications in early life which are life threatening, and because of complications in the use of multiple, fragmented medical and community services and facilities. Although there was a paucity of information on the subject, an attempt was also made to assess how families functioned in using the service delivery systemıon behalf of their handicapped children.

Most children will grow and develop in relation to a pattern, 
which, though personal for each, will be considered to be within a "normal" range. These children are able to take advantage of most of the social and cultural opportunities and ultimately to become independent, adaptable, and contributing members of society. However, there are in every community some children who are significantly "different" in their mental, emotional, physical and social characteristics to a degree that necessitates extra help in order to maximize their potential. It was the differences for the child with myelomeningocele, the difficulties that surround him, and the stress experienced by the family with which the students became concerned.

It is recognized that the birth of a child with a defect can produce stress within the immediate family. However, this birth can produce a series of disturbing events involving not only the child and his family, but the extended family, friends, community, and even society. Feelings of blame, shame, misunderstanding, and disappointment can disorganize family relationships. Gaps in services and absence of needed facilities as well as the chronic financial demands may intensify family problems.

Because of the seriousness and sometimes the multiplicity of the problems, most children with myelomeningocele require additional special services over and above the required treatment for this handicap. Availability of adequate medical resources are one of the primary problems faced by this group of handicapped children, 
their families, and their communities.

Children with long-term chronic handicaps may require in addition to medical specialists, a broad range of community services that are often widely scattered among professional groups and under auspices of numerous public and private agencies located over large geographical areas. To integrate these diverse services in order to help handicapped children requires teamwork and an understanding that only through co-operation will a health care delivery system be effective.

\section{DESCRIPTION OF THE AGENCY}

The Crippled Children's Division is the designated agency for administration of federal-state programs for Crippled Children's Services. Theoretically, when a child with myelomeningocele is delivered, the attending doctor or pediatrician usually refers to a neurosurgeon immediately. Referrals of children born in other parts of the state are usually made to the Medical School Neurosurgery Department with hospitalization in Doernbecher and subsequently referred to the Crippled Children's Division for follow-up services. Families whose children are in private hospitals are usually referred by the attending neurosurgeon, particularly if the family needs financial help. Both private physicians and those on the Medical School staff want families to have the integrative services provided through 
the Crippled Children's Division Myelomeningocele program and refer to it even though the treatment is continued under private care or in the Medical School Hospital and clinics.

It is important to understand the specific nature of the Crippled Children's Division and the role it takes in relation to handicapped children in the state of Oregon. The agency has a mandatory obligation to serve all areas of the state. The primary goal is to offer diagnostic services and treatment resources to the handicapped child. This is to insure that whenever possible, all handicapped children in the state of Oregon are given a chance to reach adult life and take their place in society as well adjusted and self-sustaining citizens. The age group served is from birth to twenty-one years of age. A unique and important component of service programs is the team evaluation and consultation to physicians and other personnel in the community. The makeup of the multiple discipline team varies depending upon the nature of the individual clinic. The professions include medicine, social work, speech pathology, audiology, psychology, nutrition, nursing, dentistry, physical and occupational the rapy, and education.

The initial intent was to provide integrative help and consultation to Medical School staff involved in the treatment. As private physicians learned about the service, referrals were made with the request that the Crippled Children's Division provide periodic review 
and integrative services. This, along with extended life span of this group of children resulted in an increased program. For an illus tration of the complexity and inter-meshing of the medical care complex component, refer to Appendix A.

The Myelomeningocele Clinic within the Division assists with diagnosis and treatment planning for children with myelomeningocele and related disorders. Most children in this group need an integrated on-going plan of long-term medical care and rehabilitation. For most of the children, because of the nature of the impairment, there is no foreseeable time when a variety of medical and social services will not be needed. By helping the child and his family understand the totality of their needs and their role in following treatment recommendations, progress can eventuate. Some of the problems identified by the diagnosis of myelomeningocele are; orthopedic limitations, neurogenic bowel and bladder, kidney and bladder malfunction, and hydrocephalus. The intellectual capacity of the child will range from average to severe retardation. Institutional care may be the only alternative for a small number of patients.

The Myelomeningocele Clinic is an attempt to efficiently utilize multiple-discipline evaluations, consultations, and educational services to families, so that fragmented resources, family fears concerning the nature of the handicap, and concern for the future can be integrated into a sustained, intelligent care plan that can focus on each 
child's needs.

\section{DESCRIPTION OF MYELOMENINGOCELE}

Myelomeningocele is based on a neurological impairment involving the brain, the spinal cord and the nerves that travel from the brain and spinal cord to the muscles, glands, and skin. The chronological development of the problem is very complex and occurs during pregnancy. Some of the bony, protective covering of the spinal cord will fail to develop fully. It is a matter of degree as to how much of the spinal cord will fail to develop. It is not unusual for some of the vertebrae to be slightly incomplete, leaving the spinal cord intact. (Spina bifida occulta). However, the condition that comes to the attention of the physician is that in which the vertebrae not only fails to develop completely, but the spinal cord fails to develop into a tube and instead forms a flat plate that protrudes from the back and, rather than being covered with backbone, is covered only with membranes that normally cover the spinal cord. This results in a sac like appearing protrusion on the infant's back. The physical problems stemming from this condition are those resulting from an interruption of the central nervous system control below the level of the lesion; e.g., fecal and urinary incontinence, paralysis, kidney infection, hydrocephalus and orthopedic malformations. See Appendix B for illustration. 
The condition is, of course, visible immediately, and treatment can be started within hours. Perhaps the main reason for the lack of knowledge about the condition among the public is that until recently, most babies only survived for a few weeks and spent that time in the hospital. The parents usually never saw the infant nor were they advised as to what was wrong with it. Now, because of recent medical developments, an increase in survival rates of these children has been seen. Like many other diseases, there is probably a hereditary predisposition which is then triggered by some other factor or factors in the environment. The condition is more likely to reoccur in families, although physicians are not ready to claim that it is inherited, but rather, lean towards a poor genetic mating risk explanation.

Within the last ten years, many new medical procedures have been developed. The first surgery performed on the infant now is frequently a neurosurgical one to repair the myelomeningocele sac and by shunting procedures to ward off or minimize hydrocephalus. A common accompanying condition of myelomeningocele is hydrocephalus or cranial enlargement through pressure of fluid retention. Small plastic tubes, shunts, are inserted in the skull, which are sometimes seen behind the ears traveling down into the chest or other parts of the body. These tubes act as a pump to drain off the excess fluid. 


\section{CHAPTER II}

\section{REVIEW OF LITERATURE}

It is with this background of experience and information that the literature concerning families with chronically handicapped children was reviewed. From this review, a plan was evolved to use an exploratory-descriptive format in an effort to develop an understanding of the stresses that families with children with myelomeningocele may encounter.

After completion of the literature review, three dominant

themes were apparent; (1) purely medical aspect, (2) family crisis characteristics, and (3) treatment modalities.

Most experts now advise neurosurgical repair of the myelominingocele within the first day of life, which is claimed to reduce the extent of orthopedic damage. Eckstein's (1966) descriptive analysis study has strongly suggested that early myelomeningocele repair can often ameliorate all orthopedic problems and that the inevitable urological problems can also be minimized.

Little information was found about how the news is broken to the parents about their child's defect. Parmalee (1962) stated that the way the physician sets the stage with the parent can influence how 
he adjusts to the crisis and the successful use of occupational, physical, medical, and social services by the parents. How the parents are informed and how they are treated by both the doctor and the hospital staff are very important in this aspect. This is very difficult for the doctor because he has to initially admit that he is failing within his profession because he cannot heal the child. The parents can better accept their misfortune if the doctor can accept his inability to remove the child's handicap. Doctors may sometimes seem to come across as cold, blunt, or disinterested; when they are in reality very emotionally involved in their own helplessness.

The majority of the literature emphasized orthopedic and urological procedures to be used as the child develops. Depending upon the severity of the crippling, and the surgical procedures already performed, various methods are offered to ward off further deterioration and or to strengthen what physical resources the child does possess. This type of reporting in journals keeps specialists abreast of new, improved methods which may decrease the damage or deform.ity if employed. In the past, it was generally as sumed that the se children would not survive, but the literature stresses that it has been demonstrated that early and continued consistent treatment has extended the life span for some. No one can predict which children will survive and thus the effort is expended for every child.

In spite of family strengths, there are predictable areas and 
periods of stress for the family when faced with the task of dealing with a chronically disabled child. Shotland (1964) offers general points that families experience when in this situation. The period of unknown prior to diagnosis usually finds the parents undergoing feelings of fear, guilt, suspicion, blame, and doubt. After diagnosis, anxiety and mourning for the lost "wholeness" that follows the "truth impact" is experienced. A third point of stress occurs when the child reaches the pre-school years and begins to physically fall behind his peers. When the child faces the elementary years and the experience of separation from family members, he enters into a world he finds difficult to understand; more stress is felt by the parents. During adolescence, the child and the parents must face the demands for a curtailed future and by adulthood, reality forces a coming to terms with the future for both the family and the off-spring. Again, it is pointed out that how families cope is largely dependent upon the emotional health of the family.

More specifically, Rapoport (1962) attempts to identify the coping patterns of families immediately after the onset of a stressful experience. She tells us that crisis time is limited during which the family will try to gain a state of equilibrium, with varying positive or negative results. (Heightened tension, attempts to solve the problem, depending on the results of the problem-solving attempts, and emergency mechanisms.) 
Shotland (1964) dealt with the family stress in an extended time span and Rapoport (1962) dealt with it in the immediate stages. Both identified common family stress characteristics. There are definite feelings of guilt and ambivalence towards the child. Parents cannot project feelings of blame for the problems onto the child because this behavior is not socially acceptable. Schild (1964) discusses the anger about the narcissistic injury that most parents feel. No parent likes to be reminded that his child has a functional ceiling.

Olshansky (1962) discusses another response known as chronic sorrow. He points out that the condition is natural under most circumstances and that it is a natural response to a tragic event. Mandelbaum (1960) speaks about projection being one of the most commonly used defenses by parents coping with a defective child. Parents may look to other family members as the cause of the problem. The more intense this defense mechanism, the longer will be the duration and the greater the chances are that the child will become a part of the parents' psychological dysfunctioning. Parents with strong psychological adjustments seem better able to handle having a disabled child than those parents who were not able to gain a satis factory adjustment in prior years. The use of denial by parents is a common mechanism, sometimes manifested in the activity of shopping around for medical care.

Giving birth to a child demands many basic adjustments. Our 
society values high achievement, attractiveness, and intelligence. Parents faced with having to deal with the direct opposite often are overwhelmed by their own feelings and what they interpret as society's scorn. A disabled child will change the functioning of the family roles and relationships. Among families with myelomeningocele, Smith (1965) tells us that there are parental concerns over mental retardation, fears of having other children, the chronic financial burden that the family must face because of the long periods of hospitalization, and the cost of medical apparatus.

Reactions of guilt, self-blame, anxiety, denial, prejection, feelings of inadequacy, a sense of helplessness, myriads of questions about finances, education, and possibilities for such a child's marriage are all aspects that confront parents. Society adds to the pressure with its expectation of perfect off-spring.

Foreman (1967) feels that some parents have valid reason for bitterness. Because of tragic mis-diagnosis, the parents anticipate the child's eventual death which results in a gradual emotional detachment from the child or mourning in advance, only to become aware that the child is not going to die; but will continue to survive at a more involved level of handicappedness. There are some pregnancies which are undesired by the parents because of various marital or social crises, which are further complicated by the birth of a defective child. If the mother has either attempted or even wished for an 
abortion, it is likely that she will link up these feelings with inten-sified guilt feelings. (In some way, she feels responsible for the handicap.)

Thomas (1965) refers to the various reactions of having produced a handicapped child. Guilt, fears of having other similar children, resentment, and doubts about their capacity to manage such children plague most parents. Sometimes, stresses within the family group, even with the best of intentions, such as the total devotion of an earnest mother towards the child's interest to the point of detriment of other siblings or the husband. On the other hand, the child may be the victim of complete disinterest of mentally ill-equipped parents.

Barsch (1968) traced child-rearing practices with handicapped children; including exhaustive research into courtship, marital, and social patterns.

The treatment modality theme was found to be mainly in social work publications. Some medical journals devoted perhaps a page or a few paragraphs to the treatment modalities in existence while working with the parents.

The social worker needs to have a clear understanding of the implications of the handicapping conditions related to family stress. The social worker is one of the family's first contacts in times of stress and acts as an advocate and an interventionist in helping to 
arrange for the appropriate care. The social worker must help the parents assess symptoms in order to consult a physician about what is needed. Social workers must know the risks of delay or of getting to the wrong service. They must be conversant with the procedures in order to interpret them to the parents. To be a good consultant to families, physicians, and others involved in helping, social workers must know each patient individually and be familiar with his treatment plan.

In this area, a social worker's main concern should be with adding to the parental social functioning, which has the most direct effect on the child's social functioning. Almost all professionals, including physicians, recognize the need for skilled and expert experiences to work most successfully with these parents.

Social workers need to be aware of their own feelings if they wish to be supportive, rather than destructive. A social worker is naive if he does not realize that he is inherently relieved that this tragedy has not befallen him personally. Social workers are usually quite adept at diagnosing a problem and then devising an intervention plan that will, they are convinced, be the panacea for their client's problems. They are then decidedly impatient when their plans are not actualized or when psychological counseling does not dispel a parent's natural grief. Social workers should be aware that even if a parent can observe his plight on a conscious level, he cannot, nor 
should he attempt to abandon his chronic sorrow. Parents have a life-time to work through their particular pain and there is no reason why it must be accomplished within the time span that a given social worke $r$ is intervening with counseling. The social worker is better able to help with parental desperation if he is able to control his own frustration and irritation with the parents and if he is able to accept his own guilt feelings in common with the parents.

The diagnostic study that is prepared is not a solution but a beginning and should encompass assessment of parental strengths as well as a medical diagnosis of the child. Social workers should accept the fact, as stipulated by Olshansky, Op. Cit., that parents of handicapped children suffer from reactions of chronic sorrow and that this is a natural, rather than an abnormal response.

Aue rbach (1968) discusses the gains that parents can attain in discussion groups. Understanding children's needs at different stages of their development, examining what they expect of themselves as parents, gaining knowledge of the interaction which occurs between parent and child and siblings, and beginning to appreciate the external influences on the child and his family.

Wolfensberger (1967) urges that professions working in this area need to have positive attitudes towards the handicap, counseling competency, and an adept knowledge of the handicap, including services such as laws and resources. He feels that parents as a whole 
have been misjudged, mishandled, and misunderstood by the majority of professionals. His approach is focused more on reality problems rather than on therapy-orientation. The offering of services should be made in the spirit and willingness to extend long-term and perhaps life-long resources to the family.

In conclusion, the primary idea that seemed to thread its way through the material concerning stress was that if a family has strong, balanced interaction among its members and is not involved in old, unsolved conflicts, unmet needs, or hostilities, the chances are great that they will be able to cope with a disabled child much more appropriately than if they find themselves enmeshed in interactional disputes. 
CHAPTER III

\section{METHODOLOGY}

\section{DESCRIPTION OF SAMPLE}

The sample used in this study was a group of fifty children born between 1965 and 1970 chosen because the majority of children born before the neurosurgical advances of 1963 did not survive. This study was conducted on a chart review basis. The charts of children in the required age group were located by scanning a card index sys tem compiled by the social worker assigned to the Myelomeningocele Clinic. The presentation of the data has been arranged in such a manner that it does not violate confidentiality.

\section{DESCRIPTION OF WEIGHTING PROCEDURES}

The weighting was designed with the purpose of indicating arbitrary problem complexity on a continuum from no problem to a problem of major complexity. More importantly, the weighting procedure was used to get away from the stereotyped thinking of only one aspect of the handicap. For example, more stress would be felt if a child was non-ambulatory than if he had a minor problem in gait control. In addition, however, it was thought that the weighting would 
highlight the complexity of care which confronted families whose child had multiple handicapping conditions. For example, one child might have a minor orthopedic problem, but a severe problem urologically and/or neurosurgically. The degree of severity might be greater in all areas for some children. Complexity is due in large measure to what families have to do to maintain continuous treatment of multiple conditions.

Not all categories ranged from one to five, but the lower number reflected less severe involvement than the higher numbers, except in the mode of transportation and family-environment stress and additional illness or handicap categories. For example, one cannot say that a marital problem is more or less stressful than a delinquent family member. See the following table for a representation of the qualitative and quantitative values assigned to the sub-division alternatives.

\section{DESCRIPTION OF INSTRUMENT DESIGN}

The method of approach was of an exploratory-descriptive style. A one page form was devised in order to provide a scheme for presenting factors identified for the study as potential stress makers for the family-child system. This was accomplished by combining appropriate aspects of three previously used Crippled Children's Division chart review forms with pertinent information gathered from 
TABLE I

RATINGS OF OUTCOME

\begin{tabular}{|c|c|c|c|c|}
\hline Dimensions & Data & Weight & Meaning of Scale & Range \\
\hline Living Situation & $\begin{array}{l}\text { Natural Parents } \\
\text { One Parent } \\
\text { Step-Parent } \\
\text { Relatives } \\
\text { Foster Home } \\
\text { Child Care Facility } \\
\text { State Institution }\end{array}$ & $\begin{array}{l}1 \\
2 \\
3 \\
4 \\
5 \\
6 \\
7\end{array}$ & $\begin{array}{l}\text { Type of Residence } \\
\text { wherein the popu- } \\
\text { lation lived at } \\
\text { the time of the } \\
\text { study }\end{array}$ & $1-7$ \\
\hline $\begin{array}{l}\text { Accessibility of } \\
\text { Services } \\
\\
-25 \text { miles } \\
26-50 \text { miles } \\
51-100 \text { miles } \\
101-300 \text { miles } \\
301-500 \text { miles }\end{array}$ & $\begin{array}{l}\text { Pediatrician } \\
\text { Neurosurgeon } \\
\text { Orthopedist } \\
\text { Urologist } \\
\text { Hospital } \\
\text { Out Patient Clinic } \\
\text { Social Work } \\
\text { Physical The rapy } \\
\text { Occupational Therapy } \\
\text { Public Health }\end{array}$ & $\begin{array}{c}1 \text { for } \\
\text { each of } \\
\text { the ten } \\
\text { services }\end{array}$ & $\begin{array}{l}\text { The geographical } \\
\text { distance from avail- } \\
\text { able needed services } \\
\text { for children with } \\
\text { Myelomeningocele }\end{array}$ & $10-50$ \\
\hline
\end{tabular}


TABLE I (Continued)

\begin{tabular}{|c|c|c|c|c|}
\hline Dimensions & Data & Weight & Meaning of Scale & Range \\
\hline $\begin{array}{l}\text { Mode of Transpor- } \\
\text { tation }\end{array}$ & $\begin{array}{l}\text { Automobile } \\
\text { Bus } \\
\text { Train } \\
\text { Commercial Plane } \\
\text { Charter Plane }\end{array}$ & $\begin{array}{l}1 \\
2 \\
3 \\
4 \\
5\end{array}$ & $\begin{array}{l}\text { Shows types of trans- } \\
\text { portation available to } \\
\text { the families in the } \\
\text { sample }\end{array}$ & $1-5$ \\
\hline Financial & $\begin{array}{l}\$ 3000 \\
\$ 3000-5000 \\
\$ 5000-7000 \\
\$ 7000-9000 \\
\$ 9000+\end{array}$ & $\begin{array}{l}5 \\
4 \\
3 \\
2 \\
1\end{array}$ & $\begin{array}{l}\text { Shows the financial } \\
\text { status of the families } \\
\text { in the study }\end{array}$ & $1-5$ \\
\hline Insurance & $\begin{array}{l}\text { Full Insurance } \\
\text { Partial Insurance } \\
\text { No Insurance }\end{array}$ & $\begin{array}{l}1 \\
2 \\
3\end{array}$ & $\begin{array}{l}\text { Shows the existence of } \\
\text { insurance available to } \\
\text { the families in the } \\
\text { study }\end{array}$ & $1-3$ \\
\hline $\begin{array}{l}\text { Family- Environ- } \\
\text { ment Stress }\end{array}$ & $\begin{array}{l}\text { No Problem } \\
\text { Marital Problem } \\
\text { Sibling Rivalry } \\
\text { Parent-Child } \\
\text { Behavior Management } \\
\text { Problem }\end{array}$ & $\begin{array}{l}1 \text { for } \\
\text { each }\end{array}$ & $\begin{array}{l}\text { Shows the types of } \\
\text { problems that can cause } \\
\text { stress in any family in } \\
\text { addition to having a } \\
\text { handicapped child }\end{array}$ & \\
\hline
\end{tabular}


TABLE I (Continued)

\begin{tabular}{|c|c|c|c|c|c|}
\hline Dimensions & Data & & Weight & Meaning of Scale & Range \\
\hline $\begin{array}{l}\text { Family - Environ- } \\
\text { ment Stress } \\
\text { (Continued) }\end{array}$ & $\begin{array}{l}\text { Additional I } \\
\text { Family } M \\
\text { Delinquent }\end{array}$ & $\begin{array}{l}1 \\
\text { mbers } \\
\text { Lembers }\end{array}$ & & & \\
\hline Educational Status & $\begin{array}{l}\text { Private Pre } \\
\text { Regular Pr } \\
\text { Special Sch } \\
\text { Special Edu } \\
\text { Home Instr }\end{array}$ & $\begin{array}{l}- \text { School } \\
\text {-School } \\
\text { ol } \\
\text { cation } \\
\text { ction }\end{array}$ & $\begin{array}{l}1 \\
2 \\
3 \\
4 \\
5\end{array}$ & $\begin{array}{l}\text { Shows the degree of } \\
\text { educational needs that } \\
\text { were identified in this } \\
\text { sample, both present and } \\
\text { anticipated }\end{array}$ & $1-5$ \\
\hline Intellectual Level & $\begin{array}{l}\text { Average } \\
\text { Borderline } \\
\text { Educable } \\
\text { Trainable } \\
\text { Custodial }\end{array}$ & $\begin{array}{r}109-84 \\
83-69 \\
68-53 \\
52-37 \\
-36\end{array}$ & $\begin{array}{l}1 \\
2 \\
3 \\
4 \\
5\end{array}$ & $\begin{array}{l}\text { Shows the degree of } \\
\text { intellectual capacity } \\
\text { identified within the } \\
\text { sample }\end{array}$ & $1-5$ \\
\hline $\begin{array}{l}\text { Orthopedic } \\
\text { Involvement }\end{array}$ & $\begin{array}{l}\text { No Problem } \\
\text { Minor Prob } \\
\text { Ambulatory } \\
\text { braces } \\
\text { Ambulatory } \\
\text { crutches } \\
\text { Not Ambula }\end{array}$ & $\begin{array}{l}\text { with } \\
\text { with } \\
\text { ory }\end{array}$ & $\begin{array}{l}1 \\
2 \\
3 \\
4 \\
4 \\
5\end{array}$ & $\begin{array}{l}\text { Shows the degree of } \\
\text { orthopedic complexity } \\
\text { identified in the sample }\end{array}$ & $1-5$ \\
\hline
\end{tabular}


TABLE I (Continued)

\begin{tabular}{|c|c|c|c|c|}
\hline Dimensions & Data & Weight & Meaning of Scale & Range \\
\hline $\begin{array}{l}\text { Kidney-Bladder } \\
\text { Involvement }\end{array}$ & $\begin{array}{l}\text { No Problem } \\
\text { Partial Control } \\
\text { External Collector } \\
\text { Surgical Intervention } \\
\text { Life Threatening }\end{array}$ & $\begin{array}{l}1 \\
2 \\
3 \\
4 \\
5\end{array}$ & $\begin{array}{l}\text { Shows the degree of } \\
\text { kidney-bladder involve- } \\
\text { ment identified in the } \\
\text { sample }\end{array}$ & $1-5$ \\
\hline $\begin{array}{l}\text { Bowel Involve- } \\
\text { ment }\end{array}$ & $\begin{array}{l}\text { No Problem } \\
\text { Control by Training } \\
\text { Manual Control } \\
\text { Total Incontinence } \\
\text { Colostomy }\end{array}$ & $\begin{array}{l}1 \\
2 \\
3 \\
4\end{array}$ & $\begin{array}{l}\text { Shows the degree of } \\
\text { bowel complexity iden- } \\
\text { tified in the sample }\end{array}$ & $1-5$ \\
\hline Neurosurgical & $\begin{array}{l}\text { No Problem } \\
\text { Arrested Spontaneously } \\
\text { Surgically Arrested } \\
\text { Revised } \\
\text { Neurosurgical complications }\end{array}$ & $\begin{array}{r}1 \\
2 \\
3 \\
4 \\
4\end{array}$ & $\begin{array}{l}\text { Shows the degree of } \\
\text { neurosurgical complexity } \\
\text { identified in the } \\
\text { sample }\end{array}$ & $1-5$ \\
\hline $\begin{array}{l}\text { Additional } \\
\text { Illnesses or } \\
\text { Handicaps }\end{array}$ & $\begin{array}{l}\text { No Problem } \\
\text { Cardiac } \\
\text { Speech } \\
\text { Hearing } \\
\text { Other }\end{array}$ & $\begin{array}{l}1 \text { for } \\
\text { each }\end{array}$ & $\begin{array}{l}\text { Shows the variety of } \\
\text { miscellaneous conditions } \\
\text { that can be present in } \\
\text { addition to } \\
\text { Myelomeningocele }\end{array}$ & \\
\hline
\end{tabular}


the thesis consultant and those categorical areas that had been found to be valuable from readings and experience. To test the research potentiality of the instrument design, a pre-test was run on the charts of ten ex-patients of the Myelomingocele Clinic. The results of the pre-test indicated that the instrument was a feasible tool for the purposes of the study.

The instrument was divided into eleven main categories and seventy-five sub-categories. The complete instrument may be referred to in Appendix C.

The first main category dealt with Age and Sex. The second category dealt with the Living Situation. (Home, state institution such as Fairview Hospital and Training Center for severely mentally retarded patients, child-care facility such as Providence Child Care Center or the Waverly Children's Home, etc.)

The third area was Accessibility of Services. Ten services used by these families were identified, and these services were categorized according to the distance between the families' homes and these services.

The fourth category looked into the Modes of Transportation that are possible in public and private sectors.

The fifth category dealt with the Financial circumstances of the families.

The sixth category covered the existence and the extent of 
Insurance Coverage. Full insurance refers to those families that were able to provide complete medical coverage for their child. Partial insurance identified the families whose insurance policies only included a percentage of the medical costs over the deductible. In such cases as these, supplementation from the Crippled Children's Service Funds was frequently needed. No insurance referred to those families who were anable to procure insurance of any kind because of insurance policies with exclusion clauses pertaining to birth defects.

Family Environment Stress was the seventh category. Marital problems referred to such items as separations, requests for counseling, etc. Sibling rivalry referred to both the handicapped child's relations with his siblings and their relationships with each other. Parent-child management problems refers to parent-child conflict, parental inability to provide appropriate structure for the child, etc. Additional ill members refers to any kind of pathology affecting members other than the handicapped child. (Physical and/or emotional). Delinquent members describes any siblings or parental acting-out in opposition to the established societal norms.

The eighth category involved Educational Status which refers to the type of educational structure usually required for this group of patients. Many private facilities will not accept multiply handicapped children. The cost of tuition and transportation are deterrents in us ing them. The regular pre-school refers to those children who may 
be accepted for public supported pre-school environments. Special schools refers to those children whose physical limitations would preclude their functioning in public schools. Special education refers to provisions made in public school systems for those children who are additionally handicapped with intellectual limitations. Those who might need home instruction were identified as being physically unable to attend school or geographically isolated from educational resources, and or those who are temporarily too disabled to fit into the other four categories.

The ninth category dealt with Intellectual Levels. The Intelligence Quotient ratings were taken from the AAMD Classification system based on the WISC and Stanford-Binet. See Appendix D for a representation.

The tenth category described the area of Problem Multiplicity related to physical handicaps and included five identified areas of concern, e.g., Orthopedic, Urological, Bowel, Neurosurgical, and Additional Illnesses or Handicaps.

Minor problems in the Orthopedic section referred to minimal problems in mobility, etc. Ambulatory with braces and/or crutches referred to those children whose only prosthetic devices were bracing and/or crutches. Those children with check marks in both categories were ambulatory with the aid of both crutches and braces used simultaneously. Non-ambulatory referred to those who were 
wheel-chair bound or bed ridden. All four categories referred primarily to mobility.

Urological problems included identification of those children with partial control (dribbling), using external collecting devices, surgical intervention such as ileal loops, and life threatening urological situations such as kidney failure.

Bowel problems include control by training, (timing and diet) manual control (suppositories) and total incontinency or no control at all.

Neurosurgical problems refer mainly to the hydrocephalic situation and the involvement of the shunt to facilitate the flow of cerebral fluid through the brain and to other parts of the body. Spontaneous arrest refers to the natural abatement of the condition. Sur gical arrest ( $1-3$ and 4 or more) refers to the surgical shunting procedures and the number of necessary revisions. Neurosurgical complications are life threatening such as meningitis.

Additional Illnesses or Handicaps that were identified included cardiac problems, speech problems, hearing problems, and other miscellaneous anomalies.

The Use of Medical Services category was the eleventh main category. There were eleven subjective descriptive statements of family functioning that were identified by the Crippled Children's Myelomeningocele Clinic staff as being related to a family's 
management capabilities.

A composite Problem Multiplicity score was derived by combining the four weighted sections of Orthopedic, Kidney-Bladder, Bowel, and Neurosurgical levels to arrive at an involvement description for each child.

\section{STATISTICAL METHOD USED}

Means and standard deviations were computed on the Weighting values that were assigned to the sub-division choices. The goal was to compare the distributions and to analyze a pattern of stress situation intensity.

Modes were identified on the unweighted sections of Family Environment Stress, Method of Transportation, and Additional Illness or Handicap in the Problem Multiplicity sections to analyze similar patterns. 


\section{CHAPTER IV}

\section{FINDINGS}

Out of a total population of fifty it was found that fifty-six percent of the sample were male and forty-four percent of the sample were female. Sixty-four percent lived with their own families and the remainder resided in other living situations. It was found that ninety-six percent were Caucasians with Chicanos being the only minority group represented. Ninety percent had an automobile available (see Tables III, IV, V).

TABLE II

AGE AND SEX DISTRIBUTION

\begin{tabular}{lccc}
\hline Years & Male & Female & Percent \\
\hline-2 & 1 & 0 & 02 \\
$2-3$ & 10 & 7 & 34 \\
$3-4$ & 5 & 4 & 18 \\
$4-5$ & 8 & 5 & 26 \\
$5-6$ & 4 & 6 & 20 \\
\hline Total & 28 & 22 & 100 \\
\hline
\end{tabular}

$N=50$ 
TABLE III

DISTRIBUTION BY RACE

\begin{tabular}{lcc}
\hline Category & Total & Percent \\
\hline Caucasian & 48 & 96 \\
Black & 0 & 00 \\
Chicano & 2 & 04 \\
Oriental & 0 & 00 \\
Other & 0 & 00 \\
\hline Total & 50 & 100 \\
\hline
\end{tabular}

$N=50$

TABLE IV

LIVING SITUATION

\begin{tabular}{lcc}
\hline Category & Total & Percent \\
\hline Natural Parents & 32 & 64 \\
Step Parents & 0 & 00 \\
Foster Home & 4 & 08 \\
One Parent & 5 & 10 \\
Relatives & 2 & 04 \\
Child Care Facility & 6 & 12 \\
State Institution & 1 & 02 \\
\hline Total & 50 & 100 \\
\hline
\end{tabular}

$\mathrm{N}=50$ 
TABLE V

METHODS OF TRANSPORTATION

\begin{tabular}{lcc}
\hline Category & Total & Percent \\
\hline Automobile & 45 & 90 \\
Bus & 4 & 08 \\
Train & 0 & 00 \\
Commercial Plane & 0 & 00 \\
Charter Plane & 1 & 02 \\
\hline Total & 50 & 100 \\
\hline $\mathrm{N}=50$ & &
\end{tabular}

\section{ACCESSIBILITY OF SERVICES CATEGORY}

A scoring range from ten to fifty was established with the lowest number indicative of easy accessibility to needed medical services. The mean was 14.9 , s.d. 8.49. This shows that two-thirds of those families who utilize the needed medical services for their children live within twenty-five miles of the available service. Even though a majority of the families were in an optimistic relationship to services, the review of case material and discussion with clinic staff indicated that critical problems could develop around getting to appropriate services. For example, whenever a trip must be made, other children usually must be cared for. Some families must plan to stay for more than a day for clinic and hospitalization. If the husband 
cannot get time off (usually with loss of pay) another adult must accompany the mother if the patient is an infant. If the patient is in a one-parent family and the parent is employed, there is a threat to the job if time must be taken frequently to accompany the patient to his appointments. Our study showed that a few families (6) lived as far as 300 to 500 miles away from appropriate health care services for a child with myelomeningocele. Table VI will show the accessibility of services for families found in the sample.

\section{FINANCIAL CATEGORY}

In this category the scoring range was from one to five with the number one indicating an income of $\$ 9000$ or more and the number five indicating an income of $\$ 3000$ or less. The mean was $3.06, \mathrm{~s} . \mathrm{d}$. 1. 22, indicating that there was a predominence of low income families within the sample. With a lack of financial power it can be anticipated that the family will be unable to manage the chronic medical care that myelomeningocele children must live with. Lack of funds implies a dependency relationship for the family that can result in increased stress. See Table VII for the financial information. 
TABLE VI

ACCESSIBILITY OF SERVICES

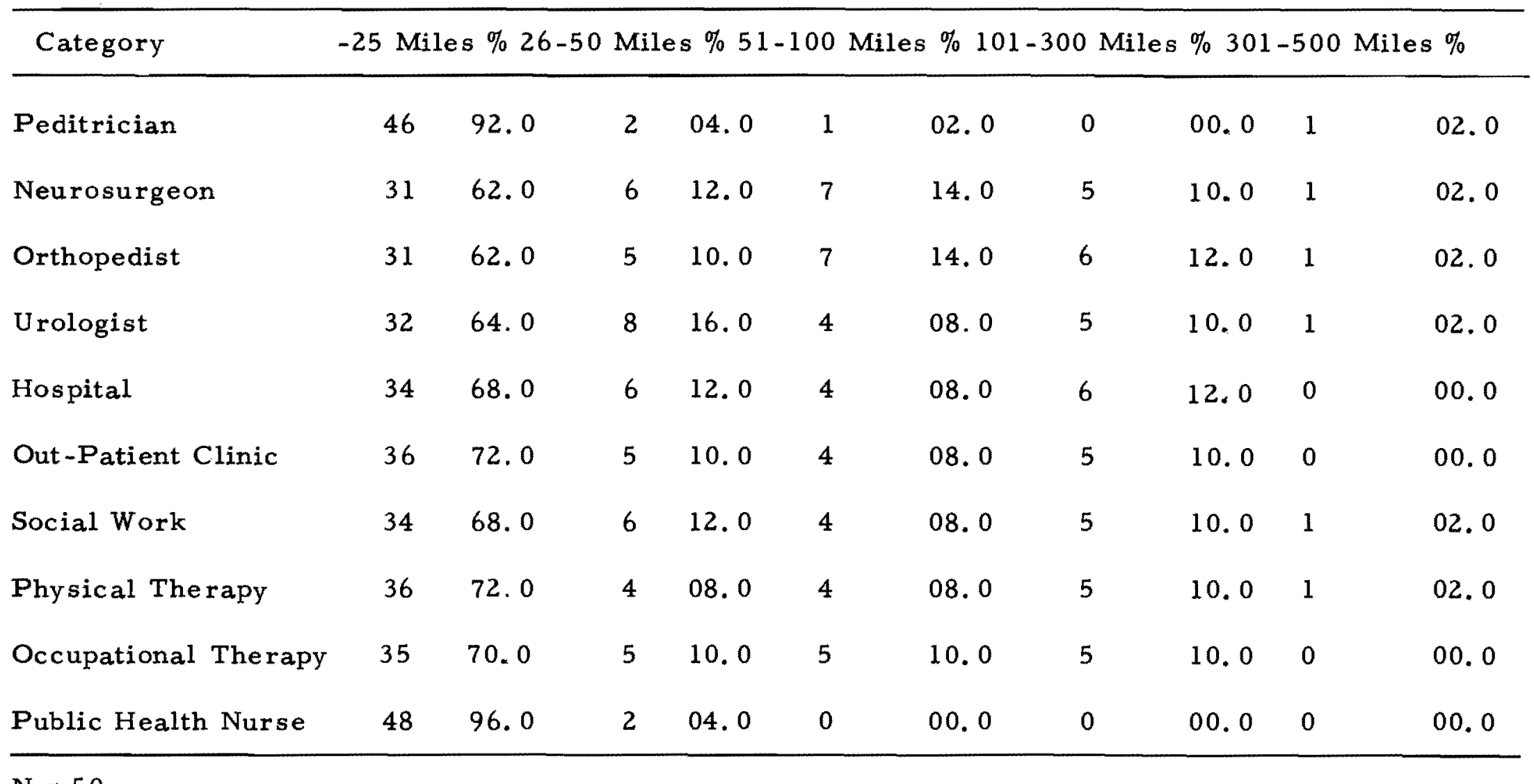

$\mathrm{N}=50$ 
TABLE VII

FINANCIAL DISTRIBUTION

\begin{tabular}{lcc}
\hline Category & Total & Percent \\
\hline$\$ 9000-$ up & 7 & 14 \\
$\$ 7000-\$ 9000$ & 5 & 10 \\
$\$ 5000-\$ 7000$ & 15 & 30 \\
$\$ 3000-\$ 5000$ & 11 & 22 \\
$\$ 3000-$ down & 12 & 24 \\
\hline Total & 50 & 100 \\
\hline
\end{tabular}

$\mathrm{N}=50$

III. INSURANCE CATEGORY

This category used the range from one to three with the number one indicating those families with full insurance and the number three indicating those families with no insurance. The mean was 2. 38 , s.d. . 43 indicating a high degree of families were without insurance. Numerically twenty-four families out of fifty were not covered by any insurance whatsoever. The inability to take care of unforeseen medical crises can increase the anxiety and stress threshhold that families have even though the Crippled Children's Division has helped those families who have partial or no insurance at all. 
TABLE VIII

INSURANCE DISTRIBUTION

\begin{tabular}{lcc}
\hline Category & Total & Percent \\
\hline Full Coverage & 3 & 06 \\
Partial Coverage & 23 & 46 \\
No Coverage & 24 & 48 \\
\hline Total & 50 & 100 \\
\hline
\end{tabular}

$\mathrm{N}=50$

\section{FAMILY ENVIRONMENTAL STRESS CATEGORY}

This category did not use a qualitative scale as it was impossible to determine for this study that one type of family stress held more value than another type of family stress. The objective of this category was to indicate what other stress factors the family may have besides the stress of raising a child with myelomeningocele. Fifty-eight percent of the families were found to have additional stressful problems. The wider a family must spread its ability to cope with stress, the greater the chances are its effectiveness will decrease. Tables IX and X will show other categories of stress that were identified. 
TABLE IX

FAMILY ENVIRONMENTAL STRESS:

NUMBERS OF FAMILIES WITH

ADDITIONAL IDENTIFIED

STRESS FACTORS

\begin{tabular}{lc}
\hline Category & Total \\
\hline No Additional Stress Factors & 21 \\
Marital Problems & 11 \\
Sibling Rivalry & 6 \\
Parent -Child Management Problems & 14 \\
Additional Ill Family Members & 14 \\
Additional Delinquent Family Members & 3 \\
\hline
\end{tabular}

TABLE X

INCIDENCE OF STRESS FACTORS

\begin{tabular}{lc}
\hline Category & Number of Families \\
\hline No Additional Stress Factors & 21 \\
One Additional Stress Factors & 21 \\
Two Additional Stress Factors & 7 \\
Three Additional Stress Factors & 1 \\
\hline
\end{tabular}




\section{EDUCATIONAL STATUS}

A scoring range from one to five was established with the number one indicating those children who would be expected to function adequately in a pre-school and the number five indicating those children who would need home instruction. The mean was $2.74, \mathrm{~s}$. d. 93. This shows us that most children in the population would be expected to use the Special School services. This has strong implications for educational services in the community. If these services are not available when the child reaches school age further stress will face the family. Lack of community based educational resources and a lack of understanding on the part of many educators can be tragic for the child with myelomeningocele who has shown progress right up to the time he must enter an educational program. It was felt by the staff that generally speaking only the schools in the urban areas can provide varied resources for multiply handicapped children and even these are seldom willing to enroll a child who is incontinent of urine and feces. 
TABLE XI

EDUCATIONAL STATUS

\begin{tabular}{lcc}
\hline Category & Total & Percent \\
\hline Private Pre-School & 3 & 06 \\
Regular Pre-School & 13 & 26 \\
Special School & 10 & 20 \\
Will Need Special Education & 19 & 38 \\
Will Need Home Instruction & 5 & 10 \\
\hline Total & 50 & 100 \\
\hline
\end{tabular}

$N=50$

See page 26 for a definition of educational categories.

\section{INTELLECTUAL LEVEL CATEGORY}

Results of this assessment indicated that the majority of the population fell into the Borderline designation. The scoring range was from one to five with the number one identifying those with average intelligence and the number five indicating those children who could be expected to need custodial care. The mean was 1.98, s.d. 1. 17. The title of the category (Borderline) emphasizes the fact that these children run the risk of being arbitrarly dealt with by the educational system. Consultation with clinic staff has indicated that, depending on the school district, the child may be placed in a mental retardation program or in a regular school program. The label of 
mental retardation can only compound the stress with which the family is faced. See Table XI.

TABLE XII

INTELLECTUAL LEVEL

\begin{tabular}{lccc}
\hline Category & IQ & Total & Percent \\
\hline Average & $(84-$ above $)$ & 24 & 48 \\
Borderline & $(69-83)$ & 11 & 22 \\
Educable & $(53-68)$ & 7 & 14 \\
Trainable & $(37-52)$ & 4 & 08 \\
Custodial & $(36-$ below $)$ & 4 & 08 \\
\hline Total & & 50 & 100 \\
\hline
\end{tabular}

$\mathrm{N}=50$

VII. USE OF MEDICAL RESOURCES

This category was designed to give a quantitative impression of how the available resources were utilized by the families in the sample. The results for this assessment were determined by interviewing the staff social worker who was assigned to the Myelomeningocele Clinic at the time of the study. There were eleven questions asked concerning the ability of the family to appropriately use the necessary medical care. All questions were equal in value with the total score indicating how well the family used the medical resources. 
The mean was 6.44 , s.d.2.30, indicating that almost one-half of the sample population could effectively use the medical services that were available to them. Although there are some broad common characteristics that families experienced when reacting to stress or crisis, families could be very individualistic when trying to manage chronically critical medical problems. Some families would never notify the Clinic when they moved. Only one family in the sample was constantly good at keeping appointments. Many families seem to use resources only at the times of crisis. The actual management of appointments at the Clinic does not require family participation. Physicians determine when a child should be seen, then send notices to the families. Few families take it upon themselves to call if they feel that their child should be seen.

In the subsections of the Problem Multiplicity Category the following results were found:

\section{ORTHOPEDIC INVOLVEMENT}

In this category the scoring range was one to five with one meaning no problem and five meaning not ambulatory. The mean was 3.80, s.d. 1.96. The results indicate that a majority of the children in the sample were strongly involved with orthopedic problems. The lack of mobility and the visibility of orthopedic problems can be traumatic to a growing child. The degree of visibility of the orthopedic 
condition can effect the self-concept of the child and the parents.

Schools again play an important role because many are not prepared to deal with the child who uses braces, crutches or a wheelchair to move around. Time is an important thing because the family must understand the long range plans that orthopedic problems require. Natural growth will provide the opportunity for important changes to take place as the child progresses. Families must learn to face long periods of inactivity waiting for their child to reach to next stage of progress.

TABLE XIII

INCIDENCE OF ORTHOPEDIC INVOLVEMENT

\begin{tabular}{lcc}
\hline Category & Total & Percent \\
\hline No Problem & 7 & 14 \\
Minor Problems & 4 & 08 \\
Ambulatory With Braces & 9 & 18 \\
Ambulatory With Crutches & 11 & 22 \\
Not Ambulatory & 19 & 38 \\
\hline Total & 50 & 100 \\
\hline
\end{tabular}

$\mathrm{N}=50$

IX. KIDNEY BLADDER INVOLVEMENT

The scoring range was from one to five with the number one 
meaning no problem and the number five meaning a life threatening situation. The mean was 2.86, s.d. 1.16. Kidney Bladder involvement appeared to be affecting a little over one-half of the children in the sample. Inability to control the bladder is one of the primary reasons for excluding a child with myelomeningocele from the school room. Continual wetness can also produce sores and irritation that must be continually managed by the parent. As the child grows, clothing for some one who is always wet becomes hard to find. Pos sible kidney failure is a life threatening situation that families must cope with continually.

TABLE XIV

INCIDENCE OF KIDNEY - BLADDER INVOLVEMENT

\begin{tabular}{lcc}
\hline Category & Total & Percent \\
\hline No Problem & 7 & 14 \\
Partial Control & 13 & 26 \\
External Control & 16 & 32 \\
Surgical Intervention & 13 & 26 \\
Life Threatening & 1 & 02 \\
\hline Total & 50 & 100 \\
\hline
\end{tabular}

$N=50$ 


\section{BOWEL INVOLVEMENT}

The scoring range went from one to five with number one indicating no problem and number five indicating the need for a colostomy. The mean was 1.84, s.d. .90 . This indicated that approximately twothirds of the patients managed to control their bowel activity through training. It should be noted that even though bowel involvement was not considered consequential for this pre-school sample it will keep children out of school programs if it cannot be controlled.

TABLE XV

INCIDENCE OF BOWEL INVOLVEMENT

\begin{tabular}{lcc}
\hline Category & Total & Percent \\
\hline No Problem & 23 & 46 \\
Control By Training & 15 & 30 \\
Manual Control & 11 & 22 \\
Total Incontinence & 0 & 00 \\
Colostomy & 1 & 02 \\
\hline Total & 50 & 100 \\
\hline $\mathrm{N}=50$ & &
\end{tabular}




\section{NEUROSURGICAL INVOLVEMENT}

The range for this category was from one to five with the number one meaning no problem and the number five meaning neurosurgical complications. The mean was 2.78, s.d. 1.46. The majority of the population appeared to have undergone surgical intervention to prevent the possibility of hydrocephalus at least three times. Each intervention is a life threatening situation that the family must learn to cope with. Twenty-four children in the sample had undergone surgical intervention one to three times. Eight had been involved with surgical intervention four or more times.

TAB LE XVI

INCIDENCE OF NEUROSURGICAL INTERVENTION

\begin{tabular}{lrc}
\hline Category & Total & Percent \\
\hline No Problem & 15 & 30 \\
Arrested Spontaneously & 1 & 02 \\
Surgically Arrested 1-3 Times & 24 & 48 \\
$\begin{array}{l}\text { Surgically Arrested 4-more } \\
\quad \text { Times }\end{array}$ & 8 & 16 \\
Neurosurgical Complications & 2 & 04 \\
\hline Total & 50 & 100 \\
\hline N $=50$ & &
\end{tabular}




\section{ADDITIONAL HANDICAP INVOLVEMENT}

This category identified other medical problems that the child with myelomeningocele was involved with in the sample. Individual medical conditions were not given values as no attempt was made to determine whether one condition produced more stress than another. Sixty percent of the sample was involved with medical problems other than those that have already been discussed. This means that even more disciplines will be involved with some families. If services are fragmented and the family is unable to manage the integration of the health care resources, the family will suffer; the child with myelomeningocele will suffer.

TABLE XVII

INCIDENCE OF ADDITIONAL HANDICAPS

\begin{tabular}{lc}
\hline Category & Total \\
\hline No Additional Handicap & 20 \\
Cardiac & 4 \\
Speech & 2 \\
Hearing & 2 \\
Other (visual handicaps, multiple anomilies, obesity, etc.) & 26 \\
\hline
\end{tabular}




\section{PROBLEM MULTIPLICITY CATEGORY}

This category attempted to bring together the four sub-categories pertaining to medical aspects discussed above. The goal was to determine from the sample the average range of medical involvement that a child with myelomeningocele may be faced with. The range for this category was from one to five with the number one meaning a minimum amount of involvement and the number five meaning a maximum amount of medical involvement. The mean was 2.99, s.d. 1.00. This shows us that the majority of the sample fell within a range from two to four, indicating a high degree multiple medical involvement. To exemplify this further it was possible to find a child with myelomeningocele in the sample with only minimal medical involvement e.g. partial control in the Kidney-Bladder Category and with no problems in the remaining three categories. However, it was statistically easier (over $50 \%$ ) to find a child with myelomeningocele in the sample who had identified problems in all of the four subcategories e.g. was not ambulatory, used an external collector, had neurosurgical complications, and controlled his bowels by training.

It is clear that parents with children with myelominingocele will have an unusual amount of potentially stressful situations with which to deal with during their child's life span. The fact that three children 
have died since the collection of material for this study began exemplifies the stress and anxiety that families with children with myelomeningocele must face. 


\section{CHAPTER V}

\section{COMMENTS AND CONCLUSIONS}

An assessment of the findings indicates that a majority of families with children with myelomeningocele found in the sample live within commuting distance to needed medical care, have transportation available to them and generally utilize the necessary medical care appropriately.

The remainder of the categories show, however, that families with children with myelomeningocele could be expected to face a variety of other problems that could only serve to exacerbate family stress. Most families were identified as having little financial power. A majority of the families had little or no medical insurance. Over one-half of the families must seek special educational resources for their children: Fifty-eight percent of the families in the sample were seen as having additional stressful problems to cope with e.g. marital problems, sibling rivalry, additional ill members. Coupled to this, the child with myelomeningocele was found to be greatly involved in a multiplicity of medical problems at many different levels of involvement e.g. orthopedic, bowel, neurosurgical, that would be expected to add to the already stressful family dynamics. 
How a family responds to a child with myelomeningocele can be anticipated in the writings of Leonard Shotland. Feelings of fear, guilt, blame and doubt are usually experienced at the time between birth and diagnosis. After diagnosis feelings of anxiety (about the future) and mourning for the loss of "completeness" will appear when the reality of the diagnosis is felt. How the family learns about the child is also a contributing factor. The literature indicates (Hare) that how parents are made aware of the condition of their child is an important factor in alleviating family stress. Staff at the Myelomeningocele Clinic related a story of how a parent was told that their new born child would die. The family arranged for the funeral, but the child continued to survive. Another parent in a parents' group related that she and her husband had been told that their child would be a vegetable and that he should be placed in an institution. Today the child is able to be at home and is far from being a vegetable. The chronic sorrow that parents experience can be identified in their child rearing patterns. Some will react by infantilizing the child as he grows e.g. one mother with a child in a wheelchair had cared for her to the extent that the youngster could not use her hands in any way. Other parents will respond by treating the child as though he had no handicap at all, "we treat him just like one of the kids". The child's reaction to the parents response to his handicap can often be seen in a loss of self esteem, dependency, and childhood depression. 
The study shows that the composite stress factors can be an important point of pressure for families. Examples from the sample include a Chicano family, geographically isolated and with a language barrier who are unable to grasp the importance of proper health care for their child. Marriage relationships appeared to be threatened under the pressure of the feelings that developed after the birth of their handicapped child e.g. guilt, blame. Family roles and relationships seemed to change when the handicapped child entered the family. Concerns about mental retardation, finances, having other children became important. With one-parent families the loneliness of being the only one to manage the care for their handicapped child often produced periods of depression for the parent.

The study clearly indicates that families with children with myelomeningocele and the affected child himself face a wide range of stress factors, emotionally, environmentally and physically. How well the family responds to these stresses will effect the progress of the child. The Myelomeningocele Clinic, in its capacity as a diagnostic center, can play an important part in relieving some of that stress by helping families cope with the multiple problems that they will face.

The coordination and continuity of health care is essential for the progress of the child. For example, the Crippled Children's Division has a satellite clinic in Eugene, Oregon in order to respond 
to the handicapped child in the southern part of the state. This can relieve some of the pressure of geographical isolation for those families that are not within commuting distance to the Crippled Children's Division clinics in the metropolitan Portland area. In a negative sense, all of the services for treatment of myelomeningocele are not available in one place and at one time. Families are usually referred by their private physician to the Crippled Children's Division for diagnostic services. If the child continues his contacts with a specific clinic, it will be for periodic team evaluation and recommendations (not treatment). Some families will use specialists in private practice while others utilize the University of Oregon Medical School facilities where they must deal with separate and autonomous outpatient clinics for treatment. A hospitalized patient is under medical supervision for the specialty for which he was admitted. Special arrangements are required for consultation and/or treatment by another specialist. The frequency of hospitalization varies but one is aware of the traumatic effects on the young child and the stress that develops from separation within the family. If treatment becomes fragmented, the family can easily lose track and will have difficulty in maintaining perspective about the rehabilitation goal for the child.

Please see Appendix A for examples of the differences in the use of medical services. Diagram A shows a family utilizing the private care system and the involvement it finds itself in concerning 
transportation, finances, between specialists and management of appointments. Diagram $B$ shows a family as it uses the facilities available at the medical school. The successful integration of health care services allows the patient and family to understand what is happening. If the family has confidence that they are actively involved in the progress of their child, the greater the likelihood that rehabilitation goals can be reached. The Myelomeningocele Clinic offers a foundation where the family can learn to understand and integrate the necessary services for their child.

\section{SUGGESTIONS FOR CHANGE}

To increase the effectiveness of the Myelomeningocele Clinic, a more formalized orientation to the medical care system that the child will be involved with should be developed. The goal would be to help the parents learn about the system so that they can use it to their advantage. This program could be the first step in helping the families develop skills in coping with the multiple stresses of raising a child with myelomeningocele.

In the area of health care accessibility, the extension of the use of satellite clinics to other areas of the state as the population warrants it would be to the advantage of the family. As population increases in the western half of the state, the development of additional satellites would be possible. 
An orientation program for personnel in education and other community services could be planned to provide understanding about the services of the clinic and the child with myelomeningocele. Through the use of seminars and involvement with children with myelomeningocele a better idea of his capacities and needs can be developed. With more awareness, hopefully more resources in education, day care and community services can be developed.

A health care program (similar to the one for the General Practitioner) should be developed for the physician with the goal of reorienting him to the impact on family dynamics when a handicapped child is diagnosed.

A program for the social work staff could include curriculum designed to increase skills in educational activity for both the parent and the community. An increase in social work staff would allow for concentration in these activities.

Families that have participated in the myelomeningocele parents group that would meet at the clinic when their child was brought in for periodic evaluations have indicated an interest in having some type of newsletter developed so that information could be shared regarding the care and management of their child e.g. where to get appropriate underwear for growing children who are incontinent.

The parent group itself served as an educational experience for some parents. It was usually made up of different parents each 
time it met, but the opportunity was there to share experiences and observe the individual differences of other children with myelomeningocele. The suggestion here is that these groups be allowed to continue and that individuals be encouraged to form new parent groups that are geographically related. The size of the groups throughout the state could serve as a measure of when and where to plan another satellite clinic.

To provide a more complete picture of the child's capacities a parental management scale should be developed and included in the records.

To increase the understanding of myelomeningocele a subscription to the English Spina Bifida Association magazine may prove to be helpful. Much of the review of literature was English in origin, leaving the impression that they were deeply involved with helping families come to terms with raising a child with myelomeningocele.

The review of literature indicated that a family that had success fully coped with crises prior to the birth of a handicapped child would have a better response to that crisis than a family that had failed to develop healthy mechanisms to combat crises. The above suggestions are hopefully designed to facilitate the families ability to face and manage the chronic medical care that comes with raising a child with myelomeningocele. 
II. IMPLICATIONS FOR FURTHER RESEARCH

The study has raised a number of questions that may be useful for further research. These questions are:

1. Recent literature (Hewett) has suggested that feelings of guilt on the part of the parent may be exaggerated because we (counselor, physician) imply that they have every reason to feel guilty. Research into just how much the family with a handicapped child deviates from the norm is needed.

2. What are the financial implications of the myelomeningocele disability for the child, family, and community?

3. Which area of the problem-multiplicity group appears to be most severe to the family (external, visible handicap or internal handicap)?

4. What management techniques can be developed to facilitate a patient-centered medical service system/

The overwhelming multiplicity of stress factors identified in this study clearly shows us that further study utilizing contacts with the actual families is needed in order to understand the complete involvement of myelomeningocele with the patient, the family, the community and the health care system. 


\section{BIB LIOGRAPHY}

Auerbach, Aline B., Parents Learn Through Discussion: Principles and Practices of Parent Group Education, New York, 1968.

Back, L. M., "Neurophysiological Processes in Human Behavior" Tulane Studies in Social Welfare, Volume III, (April, 1960)

Badell-Rivera, Angeles, et. al., Spina Bifida With Myelomeningocele; Evaluation of Rehabilitation Potential, Paper read at Forty-First Annual Session of American Congress of Physical Medicine and Rehabilitation, Dallas, Texas, August 28, 1963.

Barsch, Ray H., Ph. D., The Parent of the Handicapped Child: The Study of Child-Rearing Practices, Charles C. Thomas Publisher, American Lecture Series \#696, 1968.

Beck, Helen, "Counseling Parents with Retarded Children", in Historical Perspective on Mental Retardation During the Decade 1954-1964, Children's Bureau Publication Number 426--1964, U.S. Department of Health, Education, and Welfare, 1965.

Begab, Michael, The Mentally Retarded Child: A Guide to Services of Social Agencies, Children's Bureau Publication No. 404--1963, U. S. Department of Health, Education, and Welfare, 1963.

Blalock, Herbert, Social Statistics, McGraw-Hill Book Company, Inc., New York, 1960.

Boehm, Werner W., "Common and Specific Learnings for a Graduate School of Social Work", Journal of Education for Social Work, Volume 4, Number 2, Fall, 1968,

Brown, Mary Eleanor; and Ward, Moira M., "Toilet Problems of Seven Children with Spina Bifida, " The Physical Therapy Review, Vol, 33, no. 12, December, 1953. pp. 632-638.

Buchward, Edith, "Functional Training", The Physical Therapy Review, Vol. 29, No. 11, November, 1949.

Cohen, Pauline, "The Impact of the Handicapped Child on the Family," Social Casework, Vol. XLIII, No. 3, March, 1966. pp. 137-142. 
Dalton, Jaunita, and Helen Epstein, "Counseling Parents of Mildly Retarded Children," Social Casework, November, 1963. pp. $523-530$.

Davis, Fred, Passage Through Crisis: Polio Victims and Their Families, Robert McGinnis, ed, New York, The Bobbs-Merrill Company, Inc., 1963.

- Do You Know This Child? Author unknown, pamphlet published by the University of Oregon Medical School, n.d.

Eckstein, H.B. and G.H. Macnab, "Myelomeningocele Hydrocephalus: The Impact of Modern Treatment", Lancet, April 16, 1966. pp. $842-845$.

Fredrickson, Dorothy; and Kinsman, Deborah. "The Child With Hydrocephalus or Myelomeningocele" Physical Therapy, Vol. 46, June, 1966. pp. 606-615.

Freeman, Roger D., "Emotional Reactions of Handicapped Children" Rehabilitation Literature, Vol. SSVIII, No. 9, September 1967. pp. $274-282$.

Foekler, Merle, "Dynamics of Coping With a Medical Crisis" Public Welfare, Vol. 23, No. 1, November 1965. p. 41-57.

Goffman, Erving, Stigma: Notes on the Management of Spoiled Identity, New Jersey, Prentice Hall, 1963.

Hare, E. H., "Spina Bifida Cystica and Family Stress" British Medical Journal, September 24, 1966. pp. 757-760.

Hare, E. H., and R. M. Laurence, "The Parents of the Child With Spina Bifida", Pediatrics Digest, February, 1969. pp. 812-838.

Hill, Reuben, "Generic Features of Families Under Stress" in Crisis Intervention: Selected Readings, Howard J. Parad, ed. New York, Family Service Association of America, 1965.

Hewett, Sheila and John and Elizabeth Newson, The Family and the Handicapped Child; A Study of Cerebral Palsey Children in Their Homes, Aldine Publishing Company, Chicago, 1970.

Kozier, Ada, "Casework With Parents of Blind Children", Social Casework, January, 1962. 
Lesser, Arthur, Emotional Problems Associated With Handicapping Conditions in Children, Children's Bureau Publication No. 336-1952, U. S. Department of Health, Education, and Welfare, 1952.

Levine, Sol, "Concept of Role: Significance of Health and Handicap in a Person's Social Situation", Tulane Studies in Social Welfare, Vol. III, Apri1, 1960.

Lillywhite, Herold, "Point of View For Those Working With the Handicapped", Exceptional Children, Vol. XXV, November, 1958. pp. $101-105$.

Lorber, John, Your Child With Hydrocephalus: A Practical Guide to Parents, The Association for Spina Bifida and Hydrocephalus, City Road, London, England, 1968.

Lorber, John, Your Child With Spina Bifida; A Practical Guide to Parents, The Association for Spina Bifida and Hydrocephalus, City Road, London, England, 1968.

Mandelbaum, Arthur and M. E. Wheeler, "The Meaning of a Defective Child to Parents", Social Casework, Volume XLI No. 7, July 1960 . pp. $360-368$.

Mental Retardation: Appraisal Education Rehabilitation, Alfred A. Baumeister, ed. Aldine Publishing Company, Chicago, 1967. "Counseling the Parents of the Retarded", Wolf Wolfensburgar, pp. 329-386.

Nadal, Robert, "A Counseling Program for Parents of Severely Retarded Pre-School Children", Social Casework, February 1961. pp. 78-83.

Ojemann, Ralph H., et. al., "A Functional Analysis of Child Development Material in Current Newspapers and Magazines," Child Development, Vol. 19, March-June, 1948. pp. 208-209.

Olshansky, Simon, "Chronic Sorrow: A Response to Having a Mentally Defective Child", Social Casework, Volume XLIII No. 4, April, 1962. pp. 190-193.

Oppenheim, A. N., Questionnaire Design and Attitude Measurement, Basic Books, Inc. Publishers, New York, 1966. 
Parad, Howard and Gerald Caplan, "A Framework for Studying Families in Crisis", Social Work, Volume V, No. 3, July 1960. pp. $3-16$.

Parmalee, Arthur H. Jr., "The Doctor and the Handicapped Child", Children, Volume 9, No, 5, September-October, 1962. pp. 189194.

Polansky, Norman, Social Work Research, The University of Chicago Press, 1960.

Pryslowsky, Milton, Pediatric Conferences, Volume X, No. 4, December, 1967.

Rapoport, Lydia, "Working with Families in Crisis: An Exploration in Preventive Intervention", Social Work, Volume VII, No. 3, July, 1962. pp. 48-56.

Reid, Eleanor, "Helping Parents of Handicapped Children", Historical Perspective on Mental Retardation During the Decade 1954-1964, Children's Bureau Publication Number 426--1964. U. S. Department of Health, Education, and Welfare, 1965.

Schild, Sylvia, "Counseling With Parents of Retarded Children At Home", Social Work, Volume VIII, No. 1, January, 1964. pp. 86-91.

Sherrard, W. J. W., "The Segmental Innervation of the Lower Limb Muscles in Man", Annals of the Royal College of Surgeons of England, Vol. 35, August, 1964. pp. 106-122.

Shotland, Leonard, "Social Work Approach to the Chronically Handicapped and Their Families", Social Work, Volume VIII, No. 4, October, 1964. pp. 68-75.

Shurtleff, David B., et. al. "Hydrocephalus and Myelomeningocele: Practical Considerations", General Practice, Vol. xxxii, No. 1, July 1965. pp. 101-112.

Smith, A. D. Spina Bifida and the Total Care of Spinal Myelomeningocele, Charles C. Thomas, Pediatric Surgical Monograph Series, 1965.

Swinyard, Chester, The Child With Spina Bifida, The Association for the Aid of Crippled Children, New York, 1964. 
Valadian, Isabelle, "Physical Growth and Development: Unfolding of a Person's Potential", Tulane Studies in Social Welfare, Volume III, April, 1960.

Wilson, M. Ann, "Multidisciplinary Problems of Myelomeningocele and Hydrocephalus", Birth Defects Reprint Series from Physical Therapy, Journal of the American Physical Therapy Association, Vol, 45, No. 12, December, 1965. pp. 1139-1147.

Wilson, M. D. "Multidisciplinary Problems of Myelomeningocele and Hydrocephalus", Birth Defects Reprint Series, National Foundation, March of Dimes, 1964.

Zelditch, Morris, A Basic Course in Sociological Statistics, Columbia University Press, Holt, Rinehart and Winston, New York, 1959. 
APPENDIX A

DIAGRAMS OF SYSTEMS INTERACTION 


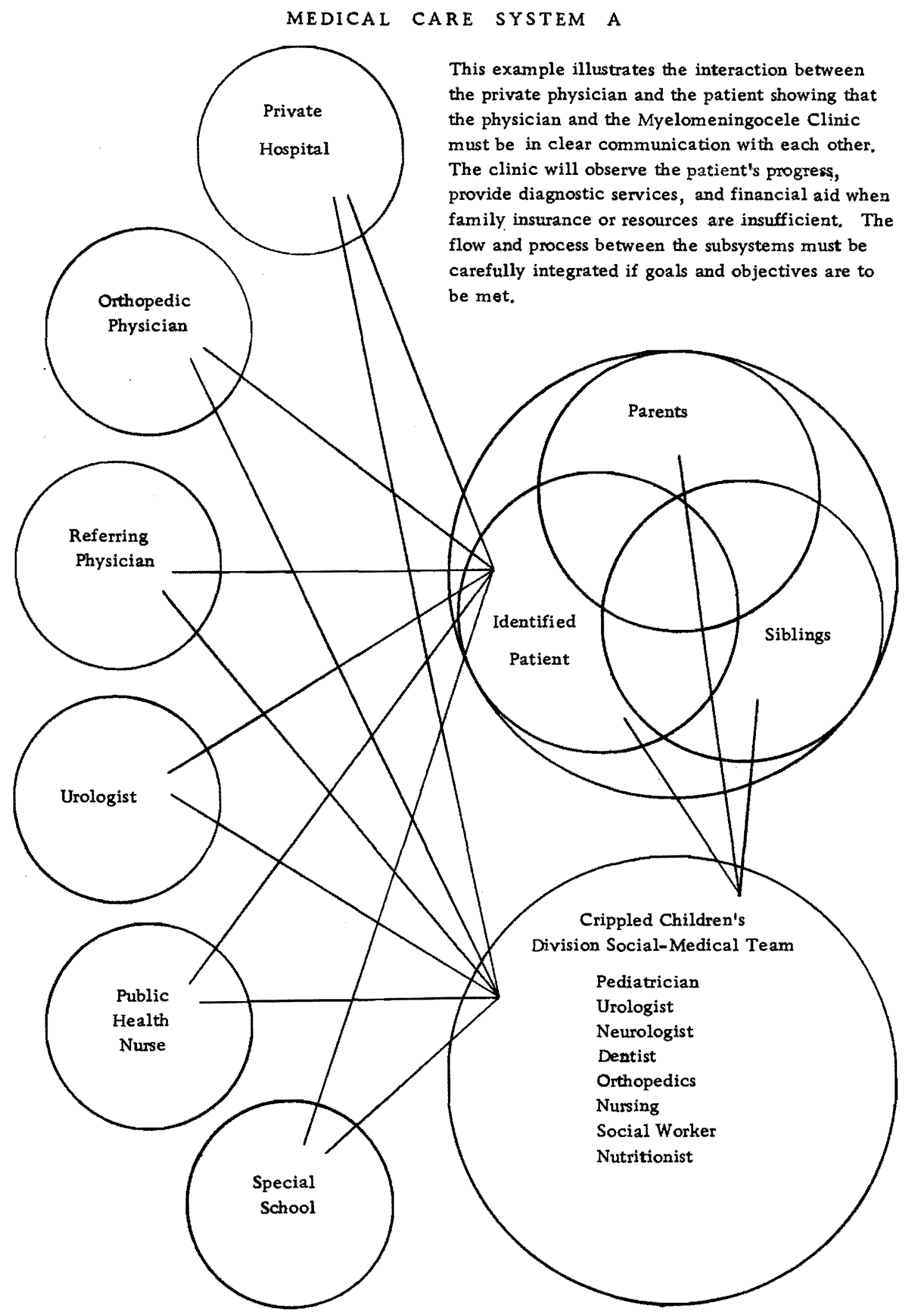




\section{MEDICAL CARE SYSTEM B}

An example of the possible degree of interaction that a patient with Myelomeningocele can be faced with. Integrating the use of these resources will facilitate the progress of the patient.

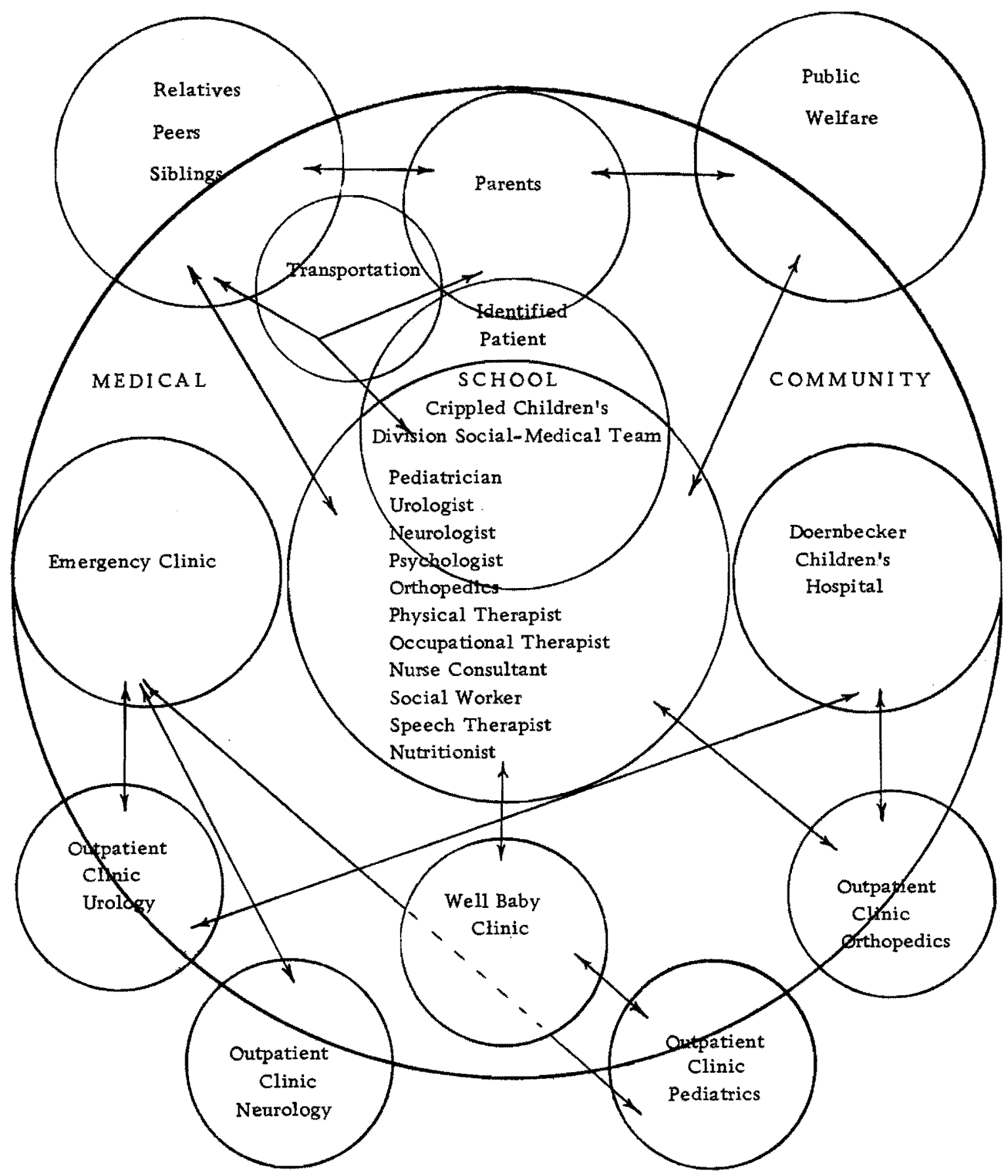


APPENDIX B

ILLUSTRATION OF MYELOMENINGOCELE 

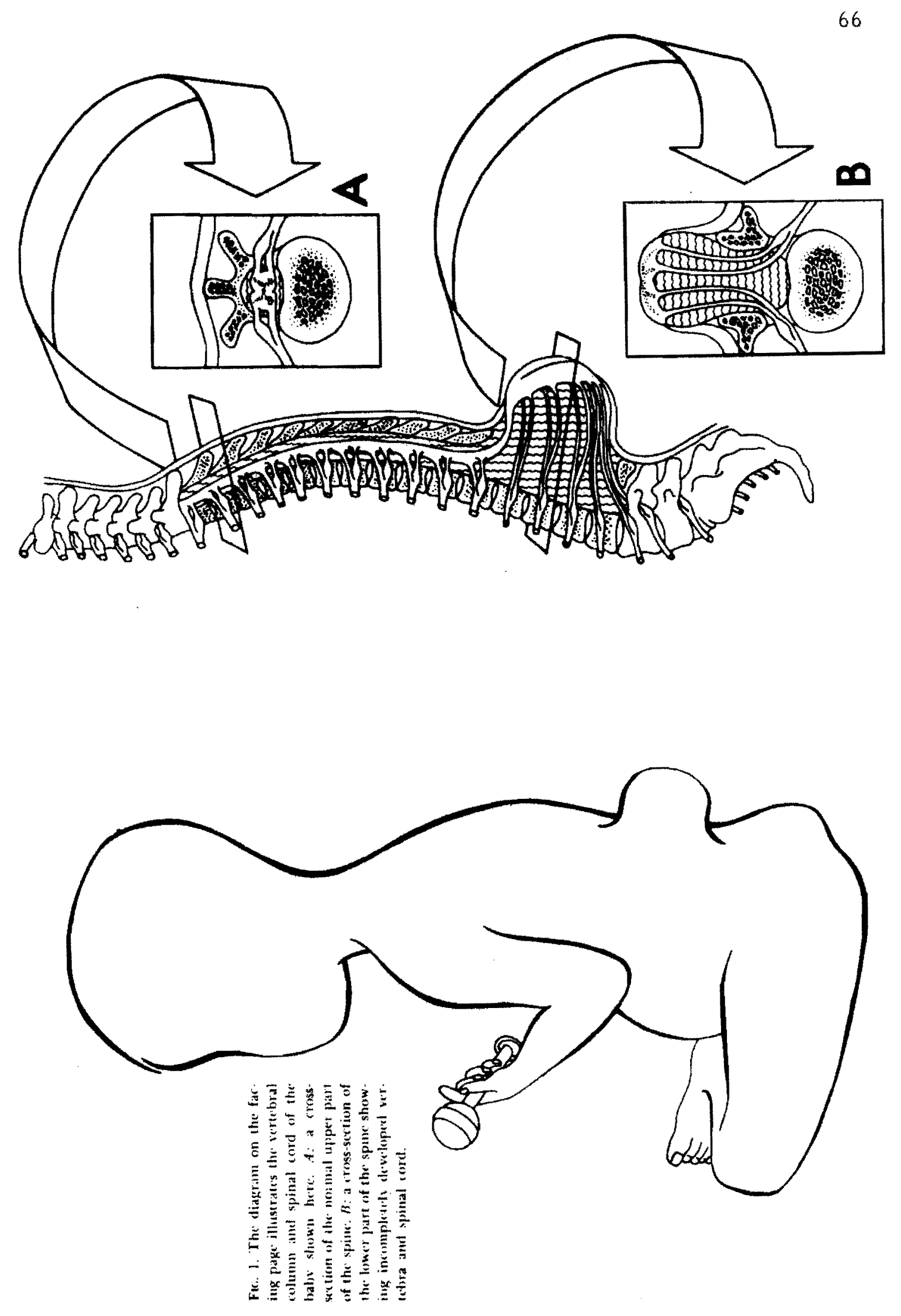
APPENDIX C

SAMP LE OF THE INSTRUMENT 


\begin{tabular}{|c|c|c|c|c|c|}
\hline AGEAND SEX & -2 years & $2-3$ years & $3-4$ years & 45 years & $5-6$ years \\
\hline \multicolumn{6}{|l|}{ Male } \\
\hline \multicolumn{6}{|l|}{ Female } \\
\hline \multirow[t]{2}{*}{ LIVING SITUATION } & Nat. Parents & Step-Parent & Foster Home & \multirow{2}{*}{$\begin{array}{l}\text { Child Care } \\
\text { Facility }\end{array}$} & \multirow{2}{*}{$\begin{array}{l}\text { State } \\
\text { Institution }\end{array}$} \\
\hline & One Parent & Relatives & & & \\
\hline \multicolumn{6}{|l|}{ ACCESSIBILITY of } \\
\hline SERVICES & -25 Miles & 26-50 Miles & $51-100$ Miles & 101-300 Miles & $301-500$ Miles \\
\hline \multicolumn{6}{|l|}{ Pediatrician or GP } \\
\hline \multicolumn{6}{|l|}{ Neurosurgeon } \\
\hline \multicolumn{6}{|l|}{ Orthopedist } \\
\hline \multicolumn{6}{|l|}{ Urologist } \\
\hline \multicolumn{6}{|l|}{ Hospital } \\
\hline \multicolumn{6}{|l|}{ OP Clinics } \\
\hline \multicolumn{6}{|l|}{ Social Work } \\
\hline \multicolumn{6}{|l|}{ Physical Therapy } \\
\hline \multicolumn{6}{|l|}{ Occupational Therapy } \\
\hline \multicolumn{6}{|l|}{$\mathrm{PHN}$} \\
\hline \multicolumn{6}{|l|}{ School } \\
\hline MODE OF TRANSPORT & Automobile & Bus & Train & $\begin{array}{l}\text { Commercial } \\
\text { Plane }\end{array}$ & $\begin{array}{l}\text { Charter } \\
\text { Plane } \\
\end{array}$ \\
\hline FINANCIAL. & $\$ 9000+$ & $\$ 7000-\$ 9000$ & $\$ 5000-\$ 7000$ & $\$ 3000-\$ 5000$ & $-\$ 3000$ \\
\hline INSURANCE & Full Ins, & Partial Ins, & No Ins, & & \\
\hline \multirow{2}{*}{$\begin{array}{l}\text { FAMILY-ENVIRONMENT } \\
\text { STRESS }\end{array}$} & No problem & \multirow[b]{2}{*}{ Sib. Rivalry } & P.C Behavior & \multirow{2}{*}{$\begin{array}{l}\text { Add'I III } \\
\text { Members }\end{array}$} & \multirow{2}{*}{$\begin{array}{l}\text { Delinquent } \\
\text { Members }\end{array}$} \\
\hline & Marital Probs & & Man. Probs. & & \\
\hline EDUCATIONAL STATUS & $\begin{array}{l}\text { Private } \\
\text { Pre-School }\end{array}$ & $\begin{array}{l}\text { Regular } \\
\text { Pre-School }\end{array}$ & $\begin{array}{l}\text { Special } \\
\text { School }\end{array}$ & $\begin{array}{l}\text { Will Need } \\
\text { Spec. Educ, }\end{array}$ & $\begin{array}{l}\text { Will Need } \\
\text { Home Instruct. }\end{array}$ \\
\hline INTELLECTUAL LEVEI & $\begin{array}{l}\text { Average } \\
84-109 \\
\end{array}$ & $\begin{array}{l}\text { Borderline } \\
83-69\end{array}$ & $\begin{array}{l}\text { Educable } \\
53-68\end{array}$ & $\begin{array}{l}\text { Trainable } \\
37-52\end{array}$ & $\begin{array}{l}\text { Custodial } \\
-36 \\
\end{array}$ \\
\hline \multicolumn{6}{|l|}{ PROBLEM MUL TIPLICITY } \\
\hline Orthopedic & No Problem & $\begin{array}{l}\text { Minor } \\
\text { Problem } \\
\end{array}$ & $\begin{array}{l}\text { Ambulatory } \\
\text { with Braces }\end{array}$ & $\begin{array}{l}\text { Ambulatory } \\
\text { with Crutches }\end{array}$ & $\begin{array}{l}\text { Not } \\
\text { Ambulatory }\end{array}$ \\
\hline Kidney-Bladder & No Problem & $\begin{array}{l}\text { Partial } \\
\text { Control } \\
\end{array}$ & $\begin{array}{l}\text { External } \\
\text { Collector }\end{array}$ & $\begin{array}{l}\text { Surgical } \\
\text { Intervention }\end{array}$ & $\begin{array}{l}\text { Life } \\
\text { Threatening } \\
\end{array}$ \\
\hline Bowel & No Problem & $\begin{array}{l}\text { Control by } \\
\text { Training }\end{array}$ & $\begin{array}{l}\text { Manual } \\
\text { Control }\end{array}$ & $\begin{array}{l}\text { Total } \\
\text { Incontinence }\end{array}$ & Colostomy \\
\hline Neurosurgical & No Problem & $\begin{array}{l}\text { Arrested } \\
\text { Spontaneously }\end{array}$ & $\begin{array}{l}\text { Surgically } \\
\text { Arrested 1-3 }\end{array}$ & $\begin{array}{l}\text { Revised } \\
4 \text { or More }\end{array}$ & $\begin{array}{l}\text { Neurosurgical } \\
\text { Complications }\end{array}$ \\
\hline $\begin{array}{l}\text { Additional Illness } \\
\text { or Handicaps }\end{array}$ & No Problem & Cardiac & Speech & Hearing & Other \\
\hline
\end{tabular}

USE OF MEDICAL RESOURCES

Aware af multiple problems, doesn't focus on one to the exclusion of others.

Seems to understand relationship between Crippled Children Clinics and treatment resources required for patient.

Assumes responsibility for sustaining treatment, for requesting and keeping appointments with private physicians and /or Medical School clinies.

Does not need direction and/or reminders by Crippled Children's Division team in order to maintain integration and continuity.

Notifies when authorizations are needed and/or financial circumstances or phone and address change.

Sufficiently conscious of hazards of decubiti.

Voluntarily seeks consultation with Public Health Nurse.

Uses social work services for integration of fragmented services,

Uses social work services for educational planning.

Uses social work services for emotional support.

Uses social work services for information about community services. 
APPENDIX D 
CLASSIFICA TION OF IQ SCORES

\begin{tabular}{|c|c|c|c|}
\hline IQ RANGE & STANFORD-BINET & WECHSLER & NEW STANFORD-BINET \\
\hline Above 140 & Genius or near-genius & Very superior & Very superior \\
\hline $130-139$ & Very superior & Very superior & Superior \\
\hline $120-129$ & Very superior & Superior & Superior \\
\hline $110-119$ & Superior & Bright normal & High average \\
\hline $90-109$ & Normal & Nomal or average & Normal or average \\
\hline $80-89$ & Dullness & Dull normal & Low average \\
\hline $70-79$ & Borderline deficiency & Borderline & Bonderline defective \\
\hline Below 70 & $\begin{array}{l}\text { Definite feeble- } \\
\text { mindedness }\end{array}$ & Mental defective & Mentally defective \\
\hline $50-70$ & Moron & \multicolumn{2}{|c|}{ Educable } \\
\hline $20-50$ & Idiot & \multicolumn{2}{|c|}{ Trainable } \\
\hline Below 20 & Imbecile & (Below 30) & \\
\hline
\end{tabular}

\section{AAMD CLASSIFICA TION}

WISC $\quad$ S-B

-1 to $-2 S D$

85-70 84-68

Borderline

-2 to $-3 \mathrm{SD}$

$70-55$

$68-52$

Mild

-3 to $-4 S D$

$55-40$

$52-36$

Moderate

-4 to $-5 S D$

40-25

$36-20$

Severe

-5 to $-6 S D$

25

20 